Article

\title{
Coconut Leaf Age and Coconut Rhinoceros Beetle Herbivory Influence Leaflet Nutrients, Metals, and Lignin
}

\author{
Thomas E. Marler (1) \\ College of Natural and Applied Sciences, University of Guam, UOG Station, Mangilao, GU 96923, USA; \\ thomas.marler@gmail.com; Tel.: +1-671-735-2100
}

Received: 24 April 2018; Accepted: 6 June 2018; Published: 8 June 2018

\begin{abstract}
The coconut rhinoceros beetle (CRB, Oryctes rhinoceros L.) is a serious pest of coconut (Cocos nucifera L.) in many tropical regions, however the influences of CRB herbivory on the coconut leaf chemistry are unknown. This limits our ability to predict the afterlife decomposition dynamics of the damaged coconut leaf litter. Mature green and senesced leaflet tissues were collected from coconut trees on the island of Guam, where coconut is native and CRB is invasive. Mineral, metal, and lignin concentrations were quantified to determine the nutrient limitations and the litter quality traits. Nitrogen was increased and the elements that are not resorbed during leaf senescence were decreased by the CRB damage. The important litter stoichiometric traits carbon/nitrogen and lignin/nitrogen were decreased by the CRB damage. The results indicate that CRB herbivory may limit green leaf nutrition in Guam's soils and increase the senesced leaf litter decomposition speed and nutrient turnover rates.
\end{abstract}

Keywords: Cocos nucifera; litter quality; Oryctes rhinoceros; resorption efficiency

\section{Introduction}

The pantropical coconut (Cocos nucifera L.) is a palm tree that provides all of the necessities of life $[1,2]$. The buoyant fruits lead to the hydrochory of seeds, which enables long distance oceanic dispersal, and means that the islands throughout Oceania possess high density coconut tree populations. In tropical island nations with widespread agroforests, the coconut is almost always a prominent component of the emergent canopy. Under these settings, horticultural care is provided, but few or no fertilizer inputs are included in the agroforest management. Therefore, an understanding of nutrient turnover is needed to sustainably manage these agroforests.

The coconut rhinoceros beetle (Oryctes rhinoceros L., Coleoptera: Scarabaeidae) is native to the Asian tropics [3,4]. The large adults damage coconut trees by boring into the young green tissues which are positioned at the apex of the stem, to feed on the sap. In the process, they cut through the emerging leaves, causing damage to the unfolded leaflets. Characteristic V-shaped cuts in the leaflets (Figure 1) and large holes through the petiole or rachis become visible, as the damaged leaves expand from the stem apex.

In geographic regions where both coconut and the beetle are indigenous, the pest infests widespread populations, but causes minimal damage to individual tree health (Figure 1a). However, in geographic regions where the coconut is native and the beetle is invasive, the damage can be extreme (Figure $1 \mathrm{~b}$ ) and ultimately lethal for the trees. The indirect consequences of coconut rhinoceros beetle (CRB) herbivory, such as the modifications to the leaf and the litter chemistry, and how these modifications affect the litter decomposition have not been studied to date. The direction and extent of changes to the litter quality caused by insect herbivory are not universal. Following herbivory, 
the litter quality and the speed of litter decomposition can be increased or decreased, depending on the host-herbivore combination [5-7]. Therefore, information on the leaf and litter chemistry changes following CRB herbivory is needed to better inform horticultural decisions and to improve the management of plant nutrition in low input agroforest systems containing coconut trees with CRB infestations.

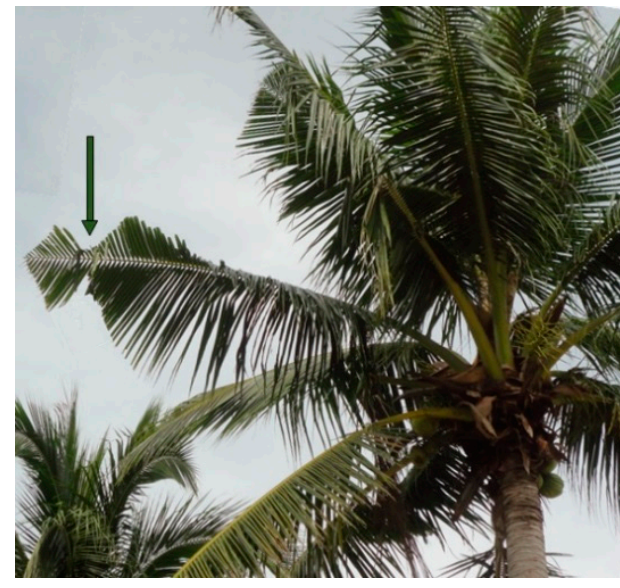

(a)

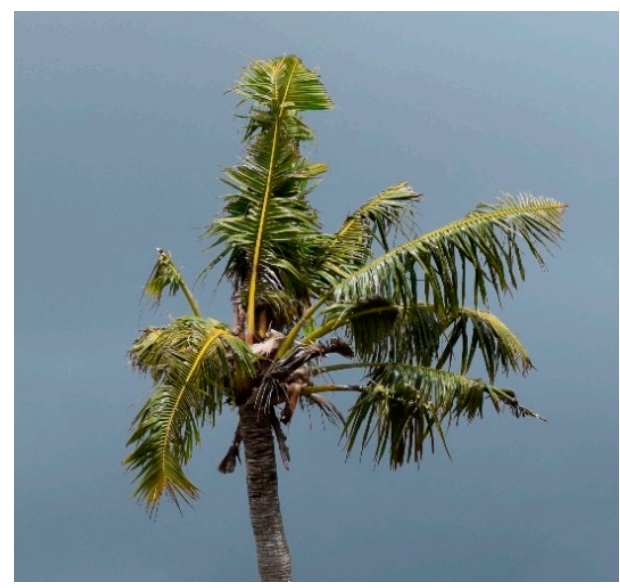

(b)

Figure 1. The appearance of coconut leaves following herbivory by coconut rhinoceros beetle (CRB). (a) CRB herbivory in northern Samar, Philippines showing characteristic sparse damage in the geographic regions where CRB is native (green arrow); (b) CRB herbivory on Guam showing the extensive health-compromising damage in geographic regions where CRB is invasive.

My primary objective is to quantify the changes in the coconut leaflet chemistry following CRB herbivory on the island of Guam, where the coconut is native but CRB is non-native. My secondary objective is to determine if changes in the senesced leaflet quality predict a change in the speed of litter decomposition. The results will add the coconut-CRB system to the accumulating case studies which help to build a predictable universal model of how insect herbivory alters litter decomposition and other ecosystem properties.

\section{Materials and Methods}

Ten locations in northern Guam were identified with high density, mature, unmanaged coconut trees, and these were treated as ten replications. At least five trees at each location were used to collect the leaflets during 10-15 September 2017. Trees were selected that exhibited some CRB-damaged leaves and some undamaged leaves, which were within the stem height range of 3-4 $\mathrm{m}$. These trees were not among those that were heavily damaged and close to death, which could directly affect the quality of the undamaged leaflet tissue. The youngest fully expanded green leaves were selected as the green leaves. To ensure that the litter was recently senesced, desiccated litter leaflets were collected from the oldest leaves that still had green petiole and rachis and were still attached to the trees. Leaflets were collected in the vicinity of the CRB herbivory for the damaged leaves, and the undamaged leaflets were collected from leaves that exhibited no herbivory at a similar location along the rachis as the CRB herbivory on the damaged leaves. The entire leaflets were harvested from the median position of the rachis to ensure that the sampling was not biased by the position on the rachis or by the leaflet axes. All leaflets from a single location were combined into a composite sample for each of the leaf age and leaf damage categories.

The soils for all ten locations were formed from sediment overlying porous limestone on uplifted plateaus (Clayey, gibbsitic, nonacid, isohyperthermic Lithic Ustorthents) [8]. In order to fully understand the edaphic traits of the experimental sites, a soil sample from a depth of $0-15 \mathrm{~cm}$ was collected from each site and was combined into a composite sample. The $\mathrm{pH}$ was 7.5 and the 
elemental content was $7.2 \mathrm{mg} \cdot \mathrm{g}^{-1}$ nitrogen, $62.9 \mu \mathrm{g} \cdot \mathrm{g}^{-1}$ phosphorus, $129.2 \mathrm{mg} \cdot \mathrm{g}^{-1}$ carbon, $0.7 \mathrm{mg} \cdot \mathrm{g}^{-1}$ potassium, $1.2 \mathrm{mg} \cdot \mathrm{g}^{-1}$ magnesium, $56.1 \mu \mathrm{g} \cdot \mathrm{g}^{-1}$ manganese, $16.9 \mu \mathrm{g} \cdot \mathrm{g}^{-1}$ iron, $2.31 \mu \mathrm{g} \cdot \mathrm{g}^{-1}$ copper, and $83.4 \mu \mathrm{g} \cdot \mathrm{g}^{-1}$ zinc.

These field methods ensured that the known factors that may influence the leaf chemistry were controlled to the selection bias during the test of the CRB damage. The soils were homogeneous, all leaves were full sun emergent leaves, their position along the massive rachis was homogeneous, the tree height was constrained, and seasonal effects were not a factor due to the mid-September collection dates. Moreover, the influence of fertilizer on the leaf chemistry was addressed by ensuring that all of the sampled trees were never recipients of fertilizer applications.

The leaflets were stored in ambient conditions until they were prepared for chemical analysis. The leaflets were dried at $75{ }^{\circ} \mathrm{C}$ and were milled to pass through a 1-mm screen. All green and litter tissue were analyzed for essential micro and macronutrients. Total nitrogen and carbon were determined by dry combustion (FLASH EA1112 CHN Analyzer, Thermo Fisher, Waltham, MA, USA), and all other elements were determined by inductively coupled plasma optical emission spectroscopy (ICP-OES) following digestion by diethylenetriaminepentaacetic acid (Spectro Genesis; SPECTRO Analytical Instruments, Kleve, Germany) [9]. The green leaf tissue was further analyzed for metal concentration using nitric acid digestion and ICP-OES. The senesced leaflet tissue was further analyzed for lignin using the acetyl-bromide method [10].

Three statistical analyses were performed. All of the prerequisites for the parametric tests were verified. (1) The element data that were quantified in both of the leaf age categories were subjected to a two-way ANOVA, with two levels of leaf age (green leaflets and senesced leaflets) and two levels of CRB herbivory (healthy and CRB-damage). To better understand the plant nutritional status, the quotients of nitrogen/phosphorus, nitrogen/potassium, and potassium/phosphorus were calculated. These stoichiometry traits were also subjected to the two-way ANOVA. (2) The metals that were quantified in the green leaf tissue were subjected to a paired $t$-test to determine the influence of CRB herbivory on these leaf chemical traits. (3) The data collected from the senesced leaflet tissue were used to better understand the influence of CRB herbivory on litter quality. The nitrogen, phosphorus, and potassium resorption efficiencies were calculated as the percent reduction of each nutrient between the green and senesced leaves [11,12]. The relationship between the structural components and the nutrient components was determined by calculating the quotients of carbon/nitrogen, carbon/phosphorus, carbon/potassium, lignin/nitrogen, lignin/phosphorus, and lignin/potassium. Lignin, resorption efficiency, and litter stoichiometric traits were subjected to a paired $t$-test to determine the influence of CRB herbivory on litter quality. For all three analyses, means separation was conducted by the least significant difference for the response variables that exhibited significant differences.

\section{Results}

\subsection{Leaf Age and CRB Damage Interactions}

Leaf age and CRB damage did not interact for the macronutrients that were resorbed during leaf senescence. Three macronutrients exhibited a significant leaf age effect (mean of both herbivory damage categories). Nitrogen declined by $41 \%\left(\mathrm{~F}_{1,27}=86.34, p<0.0001\right)$, phosphorus declined by $19 \%\left(\mathrm{~F}_{1,27}=20.98, p<0.0001\right)$, and potassium declined by $68 \%\left(\mathrm{~F}_{1,27}=96.26, p<0.0001\right)$, as the leaves aged from mature green to senesced (Figure 2). The greatest influence of CRB herbivory on these macronutrients was on nitrogen (Table 1), as the leaves with CRB damage exhibited a nitrogen concentration that was $15 \%$ greater than the healthy leaves (mean of both age categories). Leaf age and CRB herbivory did not interact for two of the nutrients that accumulated with leaf age. Magnesium increased by $47 \%\left(\mathrm{~F}_{1,27}=38.39, p<0.0001\right)$ and boron increased by $46 \%\left(\mathrm{~F}_{1,27}=10.33, p=0.0034\right)$, as the leaves aged from green to fully senesced (Figure 3). Magnesium concentration was not influenced by 
CRB herbivory. The leaves with CRB damage exhibited boron concentration that was $30 \%$ greater than the healthy leaves (Table 1).

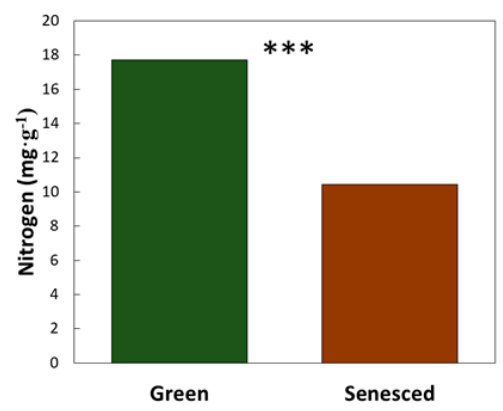

(a)

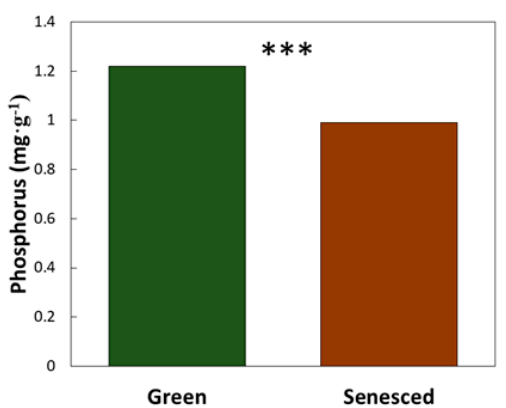

(b)

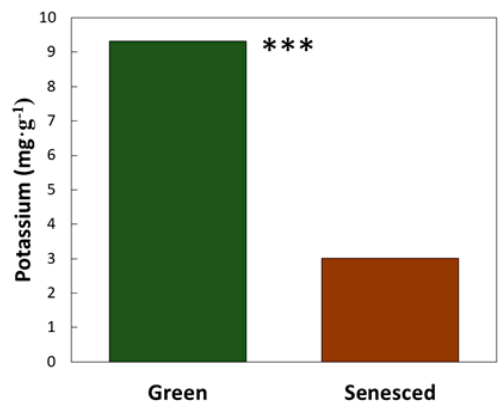

(c)

Figure 2. The influence of coconut leaf age on leaflet chemistry. (a) Nitrogen concentration; (b) Phosphorus concentration; (c) Potassium concentration. Green bars represent the youngest fully expanded leaves. Brown bars represent the senesced leaves. ${ }^{* * *}=p<0.01 . \mathrm{n}=20$.

Table 1. The influence of coconut rhinoceros beetle (CRB) herbivory on coconut leaflet chemistry. Means are a combination of the green leaves and the senesced leaves. Mean \pm standard error, $\mathrm{n}=20$.

\begin{tabular}{ccccc}
\hline Variable & Healthy & CRB-Damaged & Statistic & Significance \\
\hline Nitrogen $\left(\mathrm{mg} \cdot \mathrm{g}^{-1}\right)$ & $12.96 \pm 0.76$ & $15.20 \pm 1.18$ & $\mathrm{~F}=8.17$ & 0.0081 \\
Phosphorus $\left(\mathrm{mg} \cdot \mathrm{g}^{-1}\right)$ & $1.06 \pm 0.05$ & $1.16 \pm 0.05$ & $\mathrm{~F}=3.58$ & 0.0693 \\
Potassium $\left(\mathrm{mg} \cdot \mathrm{g}^{-1}\right)$ & $5.61 \pm 0.87$ & $6.74 \pm 0.88$ & $\mathrm{~F}=3.10$ & 0.0895 \\
Magnesium $\left(\mathrm{mg} \cdot \mathrm{g}^{-1}\right)$ & $3.56 \pm 0.22$ & $3.54 \pm 0.21$ & $\mathrm{~F}=0.00$ & 0.9622 \\
Boron $\left(\mu \mathrm{g} \cdot \mathrm{g}^{-1}\right)$ & $15.5 \pm 1.5$ & $22.1 \pm 1.8$ & $\mathrm{~F}=9.17$ & 0.0054 \\
\hline
\end{tabular}

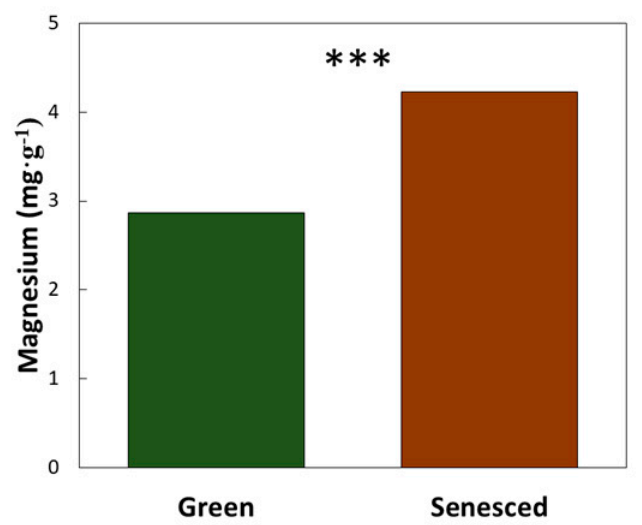

(a)

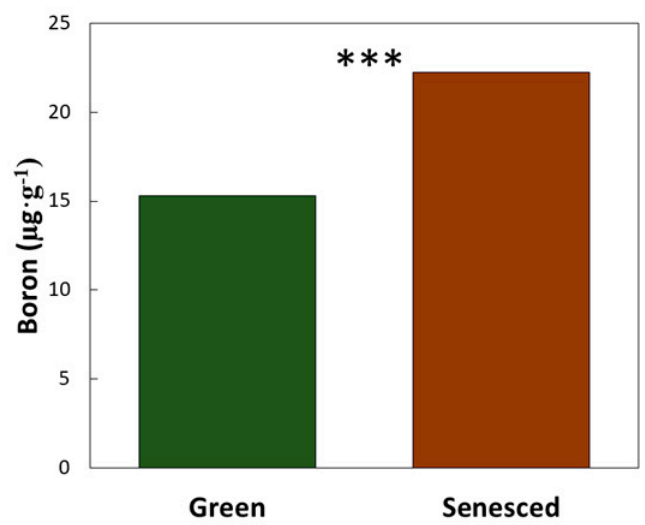

(b)

Figure 3. The influence of coconut leaf age on leaflet chemistry. (a) Magnesium concentration; (b) Boron concentration. Green bars represent the youngest fully expanded leaves. Brown bars represent the senesced leaves. $^{* * *}=p<0.01 . \mathrm{n}=20$.

Leaf age and CRB herbivory interacted for most of the nutrients that accumulated as the leaves increased in age. The interactions for carbon $\left(\mathrm{F}_{1,27}=54.29 ; p<0.0001\right)$, calcium $\left(\mathrm{F}_{1,27}=17.21 ; p=0.0003\right)$, iron $\left(\mathrm{F}_{1,27}=16.71 ; p=0.0004\right)$, manganese $\left(\mathrm{F}_{1,27}=14.08 ; p=0.0008\right)$, and zinc $\left(\mathrm{F}_{1,27}=9.08 ; p=0.0056\right)$ were significant because the green leaves exhibited concentrations that did not differ between the two CRB herbivory categories, however the healthy senesced leaflet concentrations were greater than those of the CRB-damaged senesced leaflets (Table 2). Copper was the only nutrient that was resorbed during leaf senescence that exhibited an interaction between leaf age and CRB herbivory $\left(F_{1,27}=5.42\right.$; 
$p=0.0276)$. The pattern for copper concentration was the same as for the other elements that exhibited a significant interaction, in that the green leaf tissue did not exhibit a difference between the two CRB herbivory categories, however the healthy senesced leaflet tissue exhibited a greater concentration than the CRB-damaged senesced leaflets (Table 2).

Table 2. The influence of leaf age and coconut rhinoceros beetle (CRB) herbivory on the coconut leaf chemical traits. Mean \pm standard error, $\mathrm{n}=10$.

\begin{tabular}{ccccc}
\hline Variable & Green Healthy & Green CRB-Damaged & Senesced Healthy & Senesced CRB-Damaged \\
\hline Carbon $\left(\mathrm{mg} \cdot \mathrm{g}^{-1}\right)$ & $469.1 \pm 9.6 \mathrm{a}^{\mathrm{z}}$ & $478.2 \pm 11.9 \mathrm{a}$ & $521.9 \pm 7.9 \mathrm{~b}$ & $489.9 \pm 6.3 \mathrm{ab}$ \\
Calcium $\left(\mathrm{mg} \cdot \mathrm{g}^{-1}\right)$ & $3.68 \pm 0.35 \mathrm{a}$ & $4.06 \pm 0.44 \mathrm{a}$ & $9.82 \pm 0.61 \mathrm{c}$ & $6.59 \pm 0.47 \mathrm{~b}$ \\
Iron $\left(\mu \mathrm{g} \cdot \mathrm{g}^{-1}\right)$ & $29.2 \pm 15.5 \mathrm{a}$ & $58.9 \pm 14.5 \mathrm{a}$ & $181.9 \pm 16.3 \mathrm{c}$ & $113.4 \pm 17.0 \mathrm{~b}$ \\
Manganese $\left(\mu \mathrm{g} \cdot \mathrm{g}^{-1}\right)$ & $24.0 \pm 5.1 \mathrm{a}$ & $35.1 \pm 6.7 \mathrm{a}$ & $71.9 \pm 7.1 \mathrm{c}$ & $48.4 \pm 5.6 \mathrm{~b}$ \\
Zinc $\left(\mu \mathrm{g} \cdot \mathrm{g}^{-1}\right)$ & $21.1 \pm 1.4 \mathrm{a}$ & $24.7 \pm 1.7 \mathrm{a}$ & $32.4 \pm 3.8 \mathrm{~b}$ & $21.1 \pm 2.6 \mathrm{a}$ \\
Copper $\left(\mu \mathrm{g} \cdot \mathrm{g}^{-1}\right)$ & $10.2 \pm 0.7 \mathrm{bc}$ & $9.5 \pm 0.6 \mathrm{~b}$ & $7.9 \pm 0.7 \mathrm{~b}$ & $4.5 \pm 0.4 \mathrm{a}$ \\
\hline
\end{tabular}

${ }^{\mathrm{z}}$ Means followed by the same letter within each row are not different according to the Least Significant Difference.

The nitrogen/phosphorus, nitrogen/potassium, and potassium/phosphorus quotients were not influenced by the CRB main effect or by the interaction between leaf age and CRB herbivory. The main effect of leaf age influenced all three quotients. Nitrogen/phosphorus increased from 10.75 to 14.76 $\left(\mathrm{F}_{1,27}=17.63 ; p=0.0003\right)$, nitrogen/potassium increased from 2.19 to $4.31\left(\mathrm{~F}_{1,27}=18.66 ; p=0.0002\right)$, and potassium/phosphorus declined from 7.60 to $3.04\left(\mathrm{~F}_{1,27}=60.94 ; p<0.0001\right)$ as the leaves aged from mature green to senesced leaflets.

\subsection{Metals in Green Leaves}

Nickel, chromium, cobalt, and lead contents of the green coconut leaves were greater in the CRB-damaged leaves than in the healthy leaves (Table 3). In contrast, cadmium was not influenced by CRB herbivory.

Table 3. The influence of coconut rhinoceros beetle (CRB) herbivory on green coconut leaflet metal content. Mean \pm standard error, $\mathrm{n}=10$.

\begin{tabular}{ccccc}
\hline Variable & Healthy & CRB-Damaged & Statistic & Significance \\
\hline Nickel $\left(\mu \mathrm{g} \cdot \mathrm{g}^{-1}\right)$ & $1.17 \pm 0.07$ & $2.01 \pm 0.17$ & $t=4.96$ & 0.0008 \\
Chromium $\left(\mu \mathrm{g} \cdot \mathrm{g}^{-1}\right)$ & $0.43 \pm 0.02$ & $0.51 \pm 0.02$ & $t=3.06$ & 0.0135 \\
Cobalt $\left(\mu \mathrm{g} \cdot \mathrm{g}^{-1}\right)$ & $0.04 \pm 0.00$ & $0.06 \pm 0.00$ & $t=2.84$ & 0.0195 \\
Cadmium $\left(\mu \mathrm{g} \cdot \mathrm{g}^{-1}\right)$ & $0.19 \pm 0.01$ & $0.20 \pm 0.01$ & $t=0.26$ & 0.8013 \\
Lead $\left(\mu \mathrm{g} \cdot \mathrm{g}^{-1}\right)$ & $0.54 \pm 0.03$ & $1.15 \pm 0.04$ & $t=12.16$ & $<0.0001$ \\
\hline
\end{tabular}

\subsection{Litter Quality}

Herbivory of coconut leaves by CRB did not influence senesced leaf lignin concentration $(p=0.2813)$, and the overall mean was $260.4 \mathrm{mg} \cdot \mathrm{g}^{-1}$. Similarly, herbivory of coconut leaves by CRB did not influence nitrogen resorption efficiency $(p=0.8638)$, phosphorus resorption efficiency $(p=0.3741)$, or potassium resorption efficiency $(p=0.1203)$. The mean resorption efficiency for these coconut trees was $39 \%$ for nitrogen, $20 \%$ for phosphorus, and $65 \%$ for potassium. Carbon $/$ nitrogen and lignin/nitrogen were greater in the healthy senesced coconut leaves than in the CRB-damaged senesced coconut leaves (Table 4). In contrast, the stoichiometric relations of carbon or lignin with phosphorus or potassium were arithmetically, but not significantly, greater for the healthy senesced leaflets than for the CRB-damaged senesced leaflets. 
Table 4. The influence of coconut rhinoceros beetle (CRB) herbivory on senesced coconut leaflet chemical traits. $\mathrm{n}=10$.

\begin{tabular}{ccccc}
\hline Variable & Healthy & CRB-Damaged & Statistic & Significance \\
\hline Carbon/Nitrogen & $53.6 \pm 2.6$ & $44.4 \pm 4.8$ & $t=5.97$ & 0.0002 \\
Carbon/Phosphorus & $551 \pm 38.5$ & $493 \pm 14.1$ & $t=1.45$ & 0.1801 \\
Carbon/Potassium & $240.1 \pm 42.5$ & $180.6 \pm 56.5$ & $t=1.54$ & 0.1570 \\
Lignin/Nitrogen & $26.4 \pm 1.1$ & $24.0 \pm 1.3$ & $t=2.40$ & 0.0399 \\
Lignin/Phosphorus & $271.4 \pm 21.2$ & $265.7 \pm 12.1$ & $t=0.27$ & 0.7907 \\
Lignin/Potassium & $117.8 \pm 21.3$ & $99.4 \pm 11.6$ & $t=0.98$ & 0.3532 \\
\hline
\end{tabular}

\section{Discussion}

The influence of CRB herbivory on senesced coconut leaf nutrition was more robust than on the green leaf nutrition. This was mostly borne out of muting the up-accumulation of the elements that were not resorbed during leaf senescence. All of the nutrients that exhibited a significant interaction between leaf age and CRB herbivory (Table 2) revealed the same pattern. There was no difference between the healthy and the CRB-damaged young leaf tissue, however the element concentration of the healthy senesced leaf tissue was greater than that of the CRB-damaged senesced leaf tissue. Since carbon was one of the nutrients that behaved in this manner, its influence on the litter quality exhibited the potential to drastically alter decomposition dynamics. Based on the decrease in carbon concentration alone, $\mathrm{CRB}$ herbivory may speed up coconut litter decomposition and increase the rate of nutrient turnover.

This concept may be further developed by considering the stoichiometric traits of the senesced leaf tissue. Indeed, at the global scale, climate $[13,14]$ and soil traits that define the substrate chemical and biological quality [15] exert control over the decomposition speed. However, at the local level, litter quality is the main driver of the decomposition speed [16]. The chemical and structural traits of the individual components of the leaves exert "afterlife" effects on the litter decomposition speed [17]. For example, carbon/nitrogen and lignin/nitrogen were reduced by CRB herbivory of the coconut leaves (Table 4). These litter traits are among those that often predict a more rapid litter decomposition speed and they have been highlighted as traits that insect herbivory can directly influence [5]. Based on the combined results, CRB herbivory of coconut leaves will speed up decomposition and nutrient turnover during leaf afterlife effects in agroforestry settings. This information is important to inform the sustainable production of coconut and other cash crops in these low input systems.

Much has been learned in the decades since insect herbivory was proposed as a primary regulator of primary forest productivity [18]. Moreover, the analyses of global resorption efficiency data sets have focused on identifying the universal principles to describe the various groupings, such as life-forms, phylogenies, soils, or biomes [11,19]. The direct influence of insect herbivory on leaf nutrient resorption has not received much attention. Insect herbivory may influence the leaf litter quality by inducing early leaf abscission, which circumvents the nutrient resorption that occurs during leaf senescence [20-22]. This contrasts with a second manner in which insect herbivory may influence the leaf litter quality: the induction of defensive compounds in response to the herbivory [23-25]. If the induced secondary compounds are retained during leaf senescence, then the litter is more heavily defended against by the organisms that are involved in litter decomposition, and the decomposition speed is decreased. In general, deciduous tree species with short-lived leaves may exhibit more induced biochemical responses, however evergreen tree species with long-lived leaves may exhibit more early leaf abscission responses $[5,26]$. My results indicate that, as a whole, CRB herbivory exerted a minimal influence on the resorption traits of the phloem-mobile macronutrients, with few and minimal differences between the CRB-damaged and the healthy leaves for most elements that were resorbed by coconut leaves during senescence. Nitrogen stands alone as the only resorbed element that was significantly affected by CRB herbivory. In contrast, CRB damage seemed to disrupt the bioaccumulation of elements that were not resorbed during leaf senescence, with healthy leaves accumulating more carbon and metals 
with leaf age than CRB-damaged leaves. Moreover, lignin was the only secondary metabolite that was measured in response to CRB herbivory, and my results indicate that CRB damage exerted no influence on this leaf metabolite.

This is the second case study from Guam to determine the influence of exotic insect herbivory on the leaf chemistry of a native tree species. Our other case study was Cycas micronesica K.D. Hill, which has been under attack by three invasive specialist insects [27]. The infestation by an armored scale insect, leaf chewing by larvae of a butterfly species, and leaf mining by larvae of a moth species influenced numerous nutrient and secondary compounds of senesced leaves, and the direction of the changes in the leaf chemistry by all three insects generated an increase in the litter quality [28]. The combined results of both of these studies, with two dominant native host trees and four exotic specialist pests, indicate that pests will influence the ecosystem traits by increasing the decomposition speed and the nutrient turnover rates. A full understanding of carbon and nutrient cycling within the insular forests on the Western Pacific islands is needed, and these two case studies from Guam begin to fill the current information void. More studies from the region will inform the worldwide agenda, as the literature on litter decomposition has a clear bias towards temperate climates [29].

My primary focus was to better understand senesced leaf traits to predict the influences of CRB herbivory on the afterlife dynamics of coconut leaf litter decomposition. However, my green leaf results also inform the paucity of information on nutrient limitation to primary productivity for terrestrial plants in Micronesian islands. The increase of the green coconut leaf nitrogen concentration following $\mathrm{CRB}$ herbivory contrasts with the remainder of the leaf macronutrients that were measured. While some nutrients increased in concentration with CRB damage, the concentrations of others were unaffected. Moreover, the relative increase in the concentration following CRB herbivory was not substantial for the significant elements. The nitrogen/phosphorus mean of 10.75, the nitrogen/potassium mean of 2.19, and the potassium/phosphorus mean of 7.60 indicate that nitrogen was the most limiting nutrient for these coconut trees, followed by phosphorus [30-34]. The increase in nitrogen following CRB damage was greater than phosphorus or potassium (Table 1). Based on this response alone, CRB herbivory was beneficial for alleviating the most limiting nutrient in the green coconut leaves.

The sympatric Elaeocarpus joga Merr. that grows in these same soils exhibited extremely low potassium concentration in its green leaves [35]. The coconut trees in this study did not exhibit this same potassium limitation, which indicates that, within the context of the worldwide leaf economic spectrum [36], there may be substantial variability among the native tree species with regards to nitrogen:phosphorus:potassium limitations. This leaf economic spectrum is a global database that has emerged from the contention that leaf trait trade-offs occur within and among communities [37]. More species need to be studied to determine the prevalent limiting nutrients of the native trees growing in this dominant soil series in Guam, and to determine if the range in nutrient traits conform to the predictions within the leaf economic spectrum.

The increase in the coconut leaflet's nitrogen concentration following CRB herbivory may be of critical importance in compensatory responses to partial defoliation. Three exotic pests of $C$. micronesica in Guam also increased the leaf nitrogen concentration [28], however the butterfly larvae partial defoliation led to the greatest increase. Of the three insects, the damage caused by this butterfly most closely resembled the damage to the coconut leaves caused by the CRB. First, the herbivory was restricted to young, expanding leaves, which allowed compensatory responses to occur throughout most of the leaf's lifespan. Second, the chewing caused the complete removal of some leaflet tissue, while exerting no direct damage to the leaflet portions that were not eaten. Photosynthetic compensation following partial defoliation may occur with many species, where the remaining leaf portions increase photosynthesis during recovery [38]. The increased leaflet nitrogen following the partial defoliation of coconut and C. micronesica may be indirect evidence of the increased investments into photosynthetic machinery. This could be tested during future studies.

Numerous other non-lethal insect herbivores, which are beyond the scope of this paper, reportedly feed on coconut. My objective was restricted to CRB damage, however the results indicate that other 
herbivores may possess the ability to alter coconut leaflet chemistry. Further studies with each herbivore will be required to determine the direction and the extent of these alterations. Moreover, the leaflet chemical responses to CRB damage may be a direct result of the leaflet removal per se, rather than the herbivory. This could be tested by using shears to artificially remove the leaflets, conforming with the pattern that mimics that of CRB herbivory. Although this cannot be accomplished inside the stem apex, as occurs with CRB herbivory (Figure 1a), it could be accomplished as soon as new leaves emerge.

Further research is needed to refine how CRB damage interacts with other factors that are known to influence leaflet chemistry. Season of year, edaphic chemical and physical properties, incident light within the full sun-shade spectrum, leaf age, plant size, and the location of leaflets on compound leaves are some of the environmental and plant traits that influence leaf chemistry. All of these traits were homogeneous among the sampled coconut trees in this study, however continued research could be used to determine how CRB damage behaves among variations of these other factors.

The management of fertilizer has received considerable attention within the palm horticulture literature as several palm species provide commercial products. A review of these studies is beyond the scope of this paper, as my focus was on the influence of CRB herbivory on leaflet chemistry. Applications of fertilizer alter the absolute levels of minerals and metals in palm leaves, however it also modifies the stoichiometry among the elements. Therefore, this first attempt at understanding the influence of herbivory on palm leaf chemistry was conducted without fertilizer manipulations. Moreover, this approach most closely resembled the low input agroforestry settings that characterize most of the coconut populations throughout tropical island nations. The ranges of the leaf mineral concentrations under high input horticulture management have been reported for several palm species that are important in the international food and beverage industry, including coconut [39]. My results, however, do point out that the leaf tissue sampling protocols in palm horticulture should be refined to explicitly state that no insect damage is allowable on the sampled leaves.

Acknowledgments: Support provided by the United States Department of Agriculture National Institute of Food and Agriculture McIntire Stennis project 1005274.

Conflicts of Interest: The author declares no conflict of interest. The founding sponsors had no role in the design of the study; in the collection, analyses, or interpretation of data; in the writing of the manuscript, and in the decision to publish the results.

\section{References}

1. Chan, E.; Elevitch, C.R. Cocos nucifera (coconut). In Species Profiles for Pacific Island Agroforestry; Elevitch, C.R., Ed.; Univ. of Hawai'i Press: Hōlualoa, HI, USA, 2006; pp. 277-303.

2. Ahuja, S.C.; Ahuja, S.; Ahuja, U. Coconut-History, Uses, and Folklore. Asian Agric. Hist. 2014, 18, 221-248.

3. Bedford, G.O. Observations on the biology and ecology of Oryctes rhinoceros and Scapanes australis (Coleoptera: Scarabaeidae: Dynastinae): Pests of coconut palms in Melanesia. J. Austral Entomol. Soc. 1976, 15, 241-251. [CrossRef]

4. Bedford, G.O. Biology, ecology and control of palm rhinoceros beetles. Annu. Rev. Entomol. 1980, 25, 309-339. [CrossRef]

5. Chapman, S.K.; Hart, S.C.; Cobb, N.S.; Whitham, T.G.; Koch, G.W. Insect herbivory increases litter quality and decomposition: An extension of the acceleration hypothesis. Ecology 2003, 84, 2867-2876. [CrossRef]

6. Schweitzer, J.A.; Bailey, J.K.; Hart, S.C.; Wimp, G.M.; Chapman, S.K.; Whitham, T.G. The interaction of plant genotype and herbivory decelerate leaf litter decomposition and alter nutrient dynamics. Oikos 2005, 110, 133-145. [CrossRef]

7. Fang, X.-M.; Christenson, L.M.; Wang, F.-C.; Zeng, J.-P.; Chen, F.-S. Pine caterpillar outbreak and stand density impacts on nitrogen and phosphorus dynamics and their stoichiometry in Masson pine (Pinus massoniana) plantations in subtropical China. Can. J. For. Res. 2016, 46, 601-609. [CrossRef]

8. Young, F.J. Soil Survey of Territory of Guam; United States Department of Agriculture Soil Conservation Service: Washington, DC, USA, 1988. 
9. Hou, X.; Jones, B.T. Inductively coupled plasma/optical emission spectrometry. In Encyclopedia of Analytical Chemistry; Meyers, R.A., Ed.; John Wiley \& Sons: Chichester, UK, 2000; pp. 9468-9485.

10. Iyama, K.; Wallis, A.F.A. Determination of lignin in herbaceous plants by an improved acetyl bromide procedure. J. Sci. Food Agric. 1990, 51, 145-161. [CrossRef]

11. Killingbeck, K.T. Nutrients in senesced leaves: Keys to the search for potential resorption and resorption proficiency. Ecology 1996, 77, 1716-1727. [CrossRef]

12. Aerts, R. Nutrient resorption from senescing leaves of perennials: Are there general patterns? J. Ecol. 1996, 84, 597-608. [CrossRef]

13. Berg, B.; Berg, M.P.; Bottner, P.; Box, E.; Breymeyer, A.; De Anta, R.; Couteaux, M.; Escudero, A.; Gallardo, A.; Krutz, W.; et al. Litter mass loss rates in pine forests of Europe and Eastern United States: Some relationships with climate and litter quality. Biogeochemistry 1993, 20, 127-159. [CrossRef]

14. Parton, W.; Silver, W.L.; Burke, I.C.; Grassens, L.; Harmon, M.E.; Currie, W.S.; King, J.Y.; Adair, E.C.; Brandt, L.A.; Hart, S.C.; et al. Global-scale similarities in nitrogen release patterns during long-term decomposition. Science 2007, 315, 361-364. [CrossRef] [PubMed]

15. Lavelle, P.; Decaëns, T.; Aubert, M.; Barot, S.; Blouin, M.; Bureau, F.; Marjerie, P.; Mora, P.; Rossi, J.P. Soil invertebrates and ecosystem services. Eur. J. Soil Biol. 2006, 42, S3-S15. [CrossRef]

16. Cornwell, W.K.; Cornelissen, J.H.C.; Amatangelo, K.; Dorrepaal, E.; Eviner, V.T.; Godoy, O.; Hobbie, S.E.; Hoorens, B.; Kurokawa, H.; Pérez-Harquindeguy, N.; et al. Plant species traits are the predominant control on litter decomposition rates within biomes worldwide. Ecol. Lett. 2008, 11, 1065-1071. [CrossRef] [PubMed]

17. Cornelissen, J.H.C.; Quested, H.M.; Gwynn-Jones, D.; Van Logtestijn, R.S.P.; De Beus, M.A.H.; Kondratchuk, A.; Callaghan, T.V.; Aerts, R. Leaf digestibility and litter decomposability are related in a wide range of subarctic plant species and types. Funct. Ecol. 2004, 18, 779-786. [CrossRef]

18. Mattson, W.J.; Addy, N.D. Phytophagous insects as regulators of forest primary production. Science 1975, 190, 515-522. [CrossRef]

19. Kobe, R.K.; Lepczyk, C.A.; Iyer, M. Resorption efficiency decreases with increasing green leaf nutrients in a global data set. Ecology 2005, 86, 2780-2792. [CrossRef]

20. James, R.; Pritchard, I.M. Influence of the holly leaf miner, Phytomyza ilicis (Diptera, Agromyzidae), on leaf abscission. J. Nat. Hist. 1988, 22, 395-402. [CrossRef]

21. Kahn, D.M.; Cornell, H.V. Leafminers, early leaf abscission, and parasitoids: A tritrophic interaction. Ecology 1989, 70, 1219-1226. [CrossRef]

22. Karban, R.; Niiho, C.C. Induced resistance and susceptibility to herbivory: Plant memory and altered plant development. Ecology 1995, 76, 1220-1225. [CrossRef]

23. Coley, P.D.; Barone, J.A. Herbivory and plant defenses in tropical forests. Annu. Rev. Ecol. Syst. 1996, 27, 305-335. [CrossRef]

24. Karban, R.; Baldwin, I.T. Induced Responses to Herbivory; University Chicago Press: Chicago, IL, USA, 1997; ISBN 9780226424965.

25. Agrawal, A.A.; Tuzun, S.; Bent, E. Induced Plant Defenses against Pathogens and Herbivores: Biochemistry, Ecology and Agriculture; American Phytopathological Society Press: Saint Paul, MN, USA, 1999.

26. Chapman, S.K.; Schweitzer, J.A.; Whitham, T.G. Herbivory differentially alters plant litter dynamics of evergreen and deciduous trees. Oikos 2006, 114, 566-574. [CrossRef]

27. Marler, T.E. Temporal variations in leaf miner, butterfly, and stem borer infestations of Cycas micronesica in relation to Aulacaspis yasumatsui incidence. HortScience 2013, 48, 1334-1338.

28. Marler, T.E.; Dongol, N. Three invasive insects alter Cycas micronesica leaf chemistry and predict changes in biogeochemical cycling. Commun. Integr. Biol. 2016, 9, e1208324. [CrossRef] [PubMed]

29. Hättenschwiler, S.; Tiunov, A.V.; Scheu, S. Biodiversity and litter decomposition in terrestrial ecosystems. Annu. Rev. Ecol. Evol. Syst. 2005, 36, 191-218. [CrossRef]

30. Koerselman, W.; Meuleman, A.F.M. The vegetation N:P ratio: A new tool to detect the nature of nutrient limitation. J. Appl. Ecol. 1996, 33, 1441-1450. [CrossRef]

31. Aerts, R.; Chapin, F.S. The mineral nutrition of wild plants revisited: A re-evaluation of processes and patterns. Adv. Ecol. Res. 2000, 30, 1-67.

32. Olde Venterink, H.; Wassen, M.J.; Verkroost, A.W.M.; de Ruiter, P.C. Species richness-productivity patterns differ between N-, P-, and K-limited wetlands. Ecology 2003, 84, 2191-2199. [CrossRef] 
33. Tessier, J.T.; Raynal, D.J. Use of nitrogen to phosphorus ratios in plant tissue as an indicator of nutrient limitation and nitrogen saturation. J. Appl. Ecol. 2003, 40, 523-534. [CrossRef]

34. Güsewell, S. N:P ratios in terrestrial plants: Variation and functional significance. New Phytol. 2004, 164, 243-266. [CrossRef]

35. Marler, T.E.; Lawrence, J.H. Leaf and soil nutrient relations of Elaeocarpus joga Merr. in oceanic island calcareous soils. HortScience 2015, 50, 1644-1649.

36. Wright, I.J.; Reich, P.B.; Westoby, M.; Ackerly, D.D.; Baruch, Z.; Bongers, F.; Cavender-Bares, J.; Chapin, T.; Cornelissen, J.H.; Diemer, M.; et al. The worldwide leaf economics spectrum. Nature 2004, 428, 821-827. [CrossRef] [PubMed]

37. Reich, P.B.; Walters, M.B.; Ellsworth, D.S. Leaf lifespan in relation to leaf, plant and stand characteristics among diverse ecosystems. Ecol. Monogr. 1992, 62, 365-392. [CrossRef]

38. Iqbal, N.; Masood, A.; Khan, N.A. Analyzing the significance of defoliation in growth, photosynthetic compensation and source-sink relations. Photosynthetica 2012, 50, 161-170. [CrossRef]

39. Broschat, T.K. Nutrient distribution, dynamics, and sampling in coconut and Canary Island date palms. J. Am. Soc. Hortic. Sci. 1997, 122, 884-890.

(C) 2018 by the author. Licensee MDPI, Basel, Switzerland. This article is an open access article distributed under the terms and conditions of the Creative Commons Attribution (CC BY) license (http://creativecommons.org/licenses/by/4.0/). 